\title{
IT Investment and Firm Performance in U.S. Retail Trade
}

\author{
Mark E. Doms* \\ Federal Reserve Bank of San Francisco \\ Ron S. Jarmin ** \\ Center for Economic Studies, U.S. Census Bureau \\ Shawn D. Klimek*** \\ Center for Economic Studies, U.S. Census Bureau
}

November 2003

\begin{abstract}
We examine the relationship between investments in information technology (IT) and two measures of retail firm performance: labor productivity and productivity growth over the 1992 to 1997 period. We use untapped firm and establishme nt micro data from the Censuses of Retail Trade and the Assets and Expenditures Survey. We show that large firms account for most retail IT investment, employment and establishment growth. We find evidence of a significant relationship between IT investment intensity and productivity growth. We found no evidence of a similar link between IT and growth in the number of establishments operated by retail firms.

Keywords: information technology, retail, productivity, establishment growth

JEL Classification: O31, L81

We want to thank Sheldon Ziman of the Census Bureau's Company Statistics Division for helping us acquire and understand data from the 1992 Asset and Expenditures survey. We also thank an anonymous referee and seminar participants at the Census Bureau, Penn State, and the OECD for helpful comments. All errors and omissions are ours. Any findings, conclusions or opinions expressed in this paper are those of the authors and do not necessarily reflect the views of the Census Bureau or the Federal Reserve System.
\end{abstract}

\footnotetext{
*Mark.Doms@sf.frb.org; Federal Reserve Bank of San Francisco, 101 Market Street, Mail Stop 1130, San Francisco, CA 94105

***Ron.S.Jarmin@ @ensus.gov; U.S. Census Bureau, 4700 Silver Hill Road, Mail Stop 6300, Washington, DC 20233

**** Shawn.D.Klimek@census.gov; U.S. Census Bureau, 4700 Silver Hill Road, Mail Stop 6300, Washington, DC 20233
} 


\section{Introduction}

The recent slowdown notwithstanding, the performance of the U.S. economy over the past decade has been impressive. The recent period of strong economic and productivity growth coincided with an investment boom, particularly in computers and other forms of information technology (IT). ${ }^{1}$ Aggregate level studies of productivity growth tend to rely on growth accounting techniques. These studies generally find that IT contributed significantly to the acceleration in productivity growth of the later half of the 1990s; in the 1990's the IT share of the capital stock grew rapidly, and therefore the IT contribution to productivity growth also grew.

However, the evidence on the relationship between IT spending and productivity at the industry, firm, or establishment level is less uniform in its findings. In fact, Stiroh (2003) lists a host of studies that examine the IT/productivity relationship. A problem with the IT/productivity micro literature, as Stiroh describes, is that results can vary tremendously depending on model specification, time period covered, and industries examined.

Perhaps the biggest hurdle facing economists in examining the IT/productivity relationship is that there is often a lack of appropriate data on IT, other inputs, and output. The sad truth is that many of the sectors where IT is used most intensively are where measurement by official economic statistics is the weakest ${ }^{2}$. One such sector is the retail trade sector. In this paper, we use previously untapped micro level data collected by the Census Bureau to analyze firm performance in the retail trade sector, and we focus primarily on the role of IT. Exploring and making these new datasets available for other researchers is one of the main contributions of this paper.

This paper also extends the rich literature that analyzes establishment and firm performance with Census micro data for the manufacturing sector to other significant portions of the economy. ${ }^{3}$ In analyzing firm performance in the retail trade sector, we face several hurdles. First, the quantity and quality of information available to measure firm or establishment productivity in the retail sector is much poorer than in manufacturing. In particular, measuring output is problematic and

\footnotetext{
${ }^{1}$ See, for example, Jorgenson, Ho, and Stiroh 2002; Oliner and Sichel 2000; Schreyer 2000.

${ }^{2}$ See Bosworth and Triplett 2000; Haltiwanger and Jarmin 2000. Statistical agencies are keenly aware of the measurement challenges facing them and that changes underway in the economy are making the task of measuring it more difficult. The Census Bureau has been aggressive in trying to address the needs of data users arising from the new economy by initiating new measurement initiatives, adding questions to existing surveys, and finding new ways to more fully utilize existing data resources (Atrostic, Gates and Jarmin 2001).

${ }^{3}$ See Bartlesman and Doms (2000) for a review of this literature.
} 
there is little information collected on inputs. We don't offer much in terms of solving these problems and follow the standard practice of measuring productivity with sales per employee. This is a simple measure and intuitively appealing for the retail sector. ${ }^{4}$

An additional hurdle in examining firm performance in the trade sector arises from the fact that the data we are using are collected in a variety of surveys using different sampling units. In manufacturing, establishment level data on the dollar value of inputs and output are collected in a single survey, the Annual Survey of Manufacturers. Unfortunately, in the trade sectors, the variables needed to construct just one key measure of firm performance, labor productivity, are scattered across different surveys that employ different sampling frames and units of observation. Below we discuss how we combined data from various sources to conduct this study. Indeed, one of the contributions of this paper is exploring how to analyze firm performance outside of the goods producing sectors using Census Bureau micro data.

We find that large firms are more productive than small firms. Small firms do not seem to benefit from increased spending on IT and high capital intensity, but large firms do. We also find that large firms who had a large share of their capital spending in IT and who had high capital intensities had significantly higher productivity growth than large firms that did not. Overall, firm investment in IT did not have a significant effect on productivity growth, although high capital intensity did have an effect.

\section{An overview of productivity in the retail trade sector}

Retail trade accounts for a large and growing portion of U.S. economic activity. The upper panel of table 1 presents nominal output by sector from BEA's Gross Product Originating Database; output corresponds to value added, so that the sum across all sectors equals GDP. In contrast to manufacturing, the share of nominal output from retail has been growing over the 1990s--nominal GDP grew at a 5.3 percent annual rate during the 1990s while the retail sector grew at a 5.7 percent rate.

A similar story holds for real output, as shown in the second panel; the retail sector grew faster than the economy as a whole. Finally, as shown in the last panel, real labor productivity growth in the retail sector also outpaced that of the rest of the economy, especially in the 19952000 period.

\footnotetext{
${ }^{4}$ However, Foster, Haltiwanger, and Krizan (2002) show that the trends in sales per employee derived from Census data follow the more elaborate measures of productivity that BLS produces.
} 
This strong productivity performance is still not well understood. The main reason for the lack of knowledge probably results from the lack of detailed datasets, as previouslymentioned. So, what is behind the improved productivity performance of the retail sector? Two of the more recent studies on the retail sector shed some light. The first study, Foster, Haltiwanger, and Krizan (2002) (hereafter referred to as FHK), decomposes aggregate productivity growth in the retail sector using data from the Censuses of Retail Trade. They find that most productivity growth comes from the net entry of establishments. That is, low productivity establishments exit and are replaced by high productivity new entrants. Looking more carefully at the characteristics of these high productivity entrants, they find that entering plants owned by existing firms are the most productive. For instance, this finding is consistent with a War-Mart type story. WalMart establishments are very productive (Mckinsey 2002). When Wal-Mart opens a new establishment, it may not be more productive than other WarMart establishments, but the new WarMart store would be more productive than the other retail stores it would displace. In this manner, productivity for the retail sector would increase, although the productivity of individual establishments does not change.

FHK demonstrate the importance of entry, exit, and changes in market shares in productivity growth in the retail sector. Their study very effectively shows the tremendous advantage of the data available at statistical agencies (such as the Census Bureau) in understanding sectoral productivity growth. However, their study also highlights a major shortcoming with data in the trade sectors; that is, by relying only on the Census of Retail Trade, FHK are not able to examine the relationship between other variables and productivity growth. This is because the Census of Retail Trade collects only a small set of variables. In contrast, the Census of Manufacturers collects a host of other information on outputs, inputs, and other variables. ${ }^{5}$

What then makes some retail firms more productive than others, and what changes have there been over the 1990s that have increased productivity of retail firms? Many factors go into the success of one retail business versus another, and during the 1990s, there was increased attention placed on IT. How IT is used in the retail sector is fascinating in terms of its evolution and in its pervasiveness through all aspects of the retail business. Mckinsey (2001) identified four areas where IT is used by retail firms; merchandise planning and management, manufacturing/sourcing, logistics/distribution, and store operations. In terms of merchandise planning and management,

\footnotetext{
${ }^{5}$ This state of affairs helps explain why there are many more studies on productivity growth that focus on manufacturing than on other sectors.
} 
retail firms use IT for such things as forecasting demand and for pricing decisions. One example of IT in the manufacturing/sourcing component is the use of IT to better coordinate production and inventories between manufacturers and retailers in the apparel industry. ${ }^{6}$ The connection between IT and logistics is commonly thought to include better management of warehouses, one area for which Wal-Mart is particularly famous. Finally, store operations have become increasingly automated, with barcodes being used to track goods faster and more accurately and management software.

Whether firms receive a high return on their IT investments depends, in part, on which investments they make in the four areas just discussed. Also, the successful implementation of IT investments depends on other business practices. For instance, there is an increasing awareness that the return to IT investments depends on other actions of firms, such as whether firms undertake complementary activities, with the most often cited being organizational structure (see Bresnahan, Brynjolfsson and Hitt (1999) and Mckinsey (2002)). Additionally, according to Mckinsey (2002), there were several areas of IT investment that simply did not payoff, in particular Customer Relationship Management software investments.

To sum up, there are a priori reasons to suspect that IT played some role in the increases in productivity in the retail sector in the 1990s. However, as FHK show, it is important to perform analysis on the retail sector using large samples of establishment or firm level data, so that not only can an IT/productivity relationship be tested, but also the importance of relative firm growth be demonstrated. As we describe below, we hope to make some contribution to the productivity/IT retail trade literature by developing datasets that have breadth (large numbers of observations that cover significant portions of the industry) and depth (datasets that have more information than just sales and employment).

\section{Data}

We use micro data from two Census Bureau surveys because no single survey collects data on all the variables we need. First, we use establishment level data from the 1992 and 1997 Censuses of Retail Trade, as did FHK. The Census of Retail Trade (CRT) contains information on the universe of retail establishments and is the source for the measures of labor productivity we use below. Unfortunately, the CRT is very limited in the number variables it collects. Therefore, to

\footnotetext{
${ }^{6}$ See Abernathy, Dunlop, Hammond, and Weil (1999) for a thorough and more fully developed analysis of this issue.
} 
construct measures of total capital and computer investment, we are forced to rely on another survey, the 1992 Assets and Expenditures Survey (AES). ${ }^{7}$ As described more fully below, combining information from these data sources was not a trivial task, mainly because the surveys have different sampling methods.

\section{A. Census of retail trade}

As part of the Economic Census carried out every 5 years, the Census Bureau collects selected data for the universe of retail establishments. In an effort to reduce reporting burden on smaller businesses, only establishments with a specified minimum number of paid employees (this number varies by industry, but is generally around 10) are canvassed. Administrative data are used for small employer and non-employer establishments that are not mailed Census forms. Data on payroll, employment, sales, location and industrial classification are obtained for all retail establishments (both the mail and non-mail segments). ${ }^{8}$

An establishment is a single physical location where business is conducted. The frame for the CRT, and other Economic Censuses, is the Standard Statistical Establishment List (SSEL). Since administrative data from the SSEL are used directly in the CRT and because the CRT and SSEL share a common structure, it is useful to briefly describe the SSEL.

The SSEL has two principal components. First, the Census Bureau receives information on taxpaying businesses from the Internal Revenue Service (IRS). This information corresponds to legal tax paying entities and the unit corresponds with the Employer Identification Number (EIN). The majority of businesses, in and outside of retail, have only one location. In these cases, the EI administrative reporting unit the Census receives from the IRS and the establishment are the same entity. When a new single unit establishment EIN arrives on IRS files, Census assigns both a Census File Number (CFN) and a Permanent Plant Number (PPN). Both numbers are unique to a physical establishment. However, the $\mathrm{CFN}$ is intended to incorporate information about the ownership of the establishment and can change as the ownership or other legal aspects of the

\footnotetext{
${ }^{7}$ Prior to 1994, the only source of investment data for the retail sector was the AES. In 1997, the AES was renamed the Business Expenditure Survey (BES) and nearly all investment questions were removed from the survey. The Census Bureau started conducting the Annual Capital Expenditures Survey (ACES) in 1994. The ACES is a firm level survey and only occasionally asks for investment by detailed type of equipment, such as computers. In 1998, the ACES asked firms to break out capital expenditures by equipment type for their company's three primary industries. Trying to reconcile the reporting units used in the 1992 AES and the 1998 ACES, in order to create time series investment data for retail, is beyond the scope of this paper. However, we hope to do this in the future.

${ }^{8}$ Additional information on merchandise lines and selected other items are collected from the mail segment. For the current analysis, we are interested only in the base information such as sales and employment.
} 
establishment change. The PPN remains the same as long as the establishment remains open in the same location, even if it changes hands.

The second component of the SSEL comes directly from Census Bureau data collections such as the Company Organization Survey (COS) and the Economic Censuses. These are used to maintain the list of multi-unit establishments (i.e., those owned by multi-location companies) and collect information on location, employment, industrial classification and other items. Multi-unit establishments are also assigned CFNs and PPNs. Again, they are unique to the establishment and the CFN contains information about the ownership of the establishment. Unlike in the single unit case, where they all refer to the same entity, the EI administrative reporting unit, the firm and the establishment can be very different for multi-units. This means the numeric identifiers: EIN, CFN and PPN potentially refer to different units. For multi-unit establishments, the CFN contains an ALPHA code, which identifies the firm that owns the establishment. An ALPHA can own many EINs, each of which can have several PPNs and CFNs associated with them.

This ID structure is mapped directly to establishments in the CRT. These IDs allow researchers to link establishments, firms and firm segments across different surveys. In most cases, these links are between like units (e.g., PPN to PPN or ALPHA to ALPHA). This is not the case when linking the AES and the CRT as our discussion of the AES below shows.

\section{B. Assets and expenditures survey}

The only available data on total capital expenditures and computer investment for the retail sector for 1992 are from the 1992 Assets and Expenditures Survey (AES). The sampling frame for the 1992 AES was the same as that for Annual and Monthly Retail Trade Surveys (ARTS). These surveys use significantly different sampling units than the establishment units used in the CRT. The 1992 AES was comprised of a list sample and an area sample. We do not use any of the data

from the area sample, so we do not discuss it here (see U.S. Census Bureau, 1996 for discussion of the area sample). The list sample has two sub-lists for different types of records, ALPHA and EI records.

Large multi-location retailers identified from the 1989 Company Organization Survey (COS) make up the first (ALPHA) list. Their establishments (and their corresponding EINs) were removed from the SSEL before drawing the EI list sample. The remaining establishments (and their corresponding EINs) make up the EI list. Most of the units in the ALPHA list are large multiunit retailers that were selected into the ARTS and, thus, the AES with certainty. These units 
typically correspond to an entire large retail company, but some larger retailers can have more that one reporting unit where the units are separated by major kind of business, and still others may have kinds of business that are out of scope for the CRT (e.g., wholesale or manufacturing establishments).

Smaller multi-unit and single unit retailers are contained in the EI sub-list. The ARTS chooses three rotating probability samples from this list and the AES uses two of the three. For all businesses in the EI list, the EIN is the sampling unit. Therefore, it is possible for a multi-unit EI list company with more than one EI to be represented in the AES more than once, but for distinct segments of the firm.

\section{Matching the AES to the CRT}

It is not possible to obtain exact unit to unit matches between the AES and the CRT for all multi-unit retailers. There is not an accurate mapping between the sampling units on the AES and the establishments in the CRT that the AES sampling units are intended to represent. This is due to timing issues relating to drawing the ARTS/AES sample and when the CRT is collected. In addition, participation in the ARTS is voluntary and the Census Bureau grants companies some latitude in how they report in order to obtain their participation in the survey.

Matching the AES to the CRT is not too problematic for EI cases since the EI sampling unit in the AES is intended to cover all establishments (usually only one) operating under a given EIN. The ALPHA cases, which account for a large amount of retail activity, are more difficult to match. The unit of analysis, in these cases, can be thought of as an ALPHA - kind of business combination. That is, the sampling unit is intended to describe the activities of a company within a given industrial classific ation.

The 1992 AES contained 20,355 EI units and 2,810 ALPHA units. The ALPHA units collapse to 2,024 ALPHA two-digit SIC combinations. We matched 15,498 of the 20,355 EI units to the CRT. These EIs corresponded to 32,731 establishments. We matched 1,631 of the 2,024 ALPHA two-digit SIC units (2,385 of the 2,810 ALPHA units) to the CRT. These companies had 228,982 establishments in the 1992 CRT. The result is a matched dataset with 17,129 firms. Note, what we are calling a firm does not always match the legal definition for many large enterprises.

The AES retail sample is intended to be representative of the retail sector. Because we did not match every AES unit to the Census, we adjust the AES sample weights as follows: 


$$
\operatorname{adjwgt}_{i j}^{s}=w g t_{i j}^{s} * \frac{\sum_{k \in A_{j}^{s}} \text { sales }_{k}}{\sum_{l \in M_{j}^{s}} \text { sales }_{l}}
$$

where $\mathrm{i}, \mathrm{k}$ and $\mathrm{l}$ index firms, $\mathrm{j}$ indexes 2-digit SIC industries and $\mathrm{s}$ indexes the pair \{EI, ALPHA\}. The term in the numerator is the weighted sum for all AES firms in industry $\mathrm{j}$ and set $\mathrm{s}$, and the term in the denominator is the same sum for those firms that we matched to the CRT. We compute adjusted weights separately for EI and ALPHA cases since the sample weights are so different (the median AES sample weight for ALPHA units in 1 and for EI units it's 15.25). Note that even after adjusting the weights, our totals will not match those in official Census publications since we are omitting the AES area sample.

\section{Comparison of our matched sample to the CRT universe}

Tables 2 and 3 contain descriptive statistics for the firm units we constructed from the CRT. All establishments, in both the 1992 and 1997 CRTs, are represented. We list the number of firms in each year as well as the number of surviving, or continuing, firms by size class. Table 2 shows that there is considerable turnover amongst retail firms, especially in the smaller size categories. More than half of the firms in the 0 to 9 size class in 1992 exit prior to 1997.

Work by FHK suggests that net entry of establishments drives most aggregate retail productivity growth over a similar time period. We do not decompose productivity growth as do FHK, but our results suggest that changes to the retail sector caused by the net entry of establishments are dominated by large continuing firms. Results in Table 2 show that large continuing retailers contributed more than two-thirds of the increase in retail establishments (26,494 of 34,980) between 1992 and 1997. Even more important, perhaps, is the fact that large retailers contributed approximately $71 \%$ of the over 2.7 million net increase in retail employment over the 1992 to 1997 period! Large retailers add more retail establishments and jobs than do their smaller counterparts and are accounting for a larger portion of overall retail activity in the U.S. While this result should seem obvious to most U.S. consumers, it is the opposite of the trends we have observed in the manufacturing sector, where large firms have reduced their employment share but have increased the productivity gap vis-à-vis small firms (Baldwin, Jarmin and Tang 2001).

Table 3 gives some basic statistics for labor productivity (sales per worker) for 1992 and 1997 and gives the average firm level change in productivity. All productivity calculations are 
nominal. The results suggest that the productivity performance of large retailers is rather similar to all but the smallest firms.

Table 4 shows descriptive statistics for our matched sample of AES-CRT data. The AES covers most large retailers with certainty in order to cover as much retail activity as possible, while holding the sample size and respondent burden to a minimum. As a result, even though our matched sample only covers 17,129 of the $1,071,737$ retail firms in the 1992 CRT, it covers a sizable portion of retail employment and sales. Productivity growth between 1992 and 1997 does not vary strikingly across the size distribution, as was the case for retail as a whole. Firms in the matched sample do tend, however, to be larger and more productive than the typical firm in the entire retail universe. However, the row showing the average weighted productivity growth for the matched sample is quite similar to the row in table 3 showing the productivity growth for all firms. Table 4 also lists means for average total and IT investment by size class. Large firms account for most retail investment - they accounted for over half of all investment in IT by retailers in 1992.

We want to measure the cross sectional variation in total and computer capital intensity. Ideally, we would want a measure of total and computer capital stocks and normalize them with some measure of size such as employment, payroll or sales. The AES asks for total capital expenditures and expenditures on selected types of equipment, such as computers. It does not collect information on stocks of IT equipment and we don't have time series data available at the firm level to construct capital stock measures. However, previous work with manufacturing data shows that the patterns of cross sectional variation in investment and capital stocks are very similar. Therefore, we proxy total capital intensity with total investment per dollar of payroll. Similarly, we proxy computer investment intensity with computer investment per dollar of payroll. We use the payroll measure available on the AES as opposed to that on the CRT to mitigate measurement error introduced by matching the two data sources.

In table 5 we provide basic statistics on establishments, employment and productivity by capital and computer investment intensity categories. Firms are categorized as having high total investment if they were above the 75th percentile of total investment spending per dollar of payroll. Similarly, firms were classified as having high IT investment if they were above the 75 th percentile of IT per dollar of payroll. The table shows striking differences in the productivity performance of firms according to capital and computer intensities. Also, establishme nt and employment growth for the matched AES-CRT sample is concentrated entirely among firms with high capital and/or 
computer intensities. The productivity growth premium to having both the high total and high computer intensities is particularly striking.

While we recognize that there are important differences across firms in different IT and capital investment groups, we also recognize that there is heterogeneity across industries. For example, the average firm size in general merchandise stores (SIC 53) is just over 200 employees as compared to just over 20 employees in food stores (SIC 54). Ultimately, we would like to look at the relationship between IT investment, capital investment, and productivity. The final two rows of Table 6 show that there is great variation in both the level and growth of productivity across retail industries. The natural log of labor productivity ranges from a low of 3.40 in eating and drinking places (SIC 58) to a high of 5.09 in automotive dealers and gasoline service stations (SIC55). The final row shows that heterogeneity also exists when looking at the productivity growth from 1992 to 1997 for firms that survive, ranging from a decline in producitvity of 7.3\% for general merchandis stores to an increase of $3.8 \%$ in automotive dealers and gasoline service stations.

As Table 7 shows, our matched data exhibits similar patterns to those described for the entire retail sector. ${ }^{9}$ Our matched data shows that average weighted capital and computer expenditures vary considerably across two-digit industries. Again, we see that general merchandise stores have much larger levels of investment at the firm level. The last two rows in the tables normalize our investment measure by payroll to account for differences in the size of firms across industries. Capital expenditures range from 13 cents per dollar of payroll in food and drinking establishments to 21.4 cents per dollar of payroll in miscellaneous retail. Computer expenditures are a significantly smaller share of payroll, with most firms in our dataset spending under a penny per dollar of payroll. ${ }^{10}$

Our regressions in the following section are a cross sectional analysis of firms present in both 1992 and 1997 using 1992 characteristics as regressors. As this section has shown, firms differ depending on investment, but also exhibit heterogeneity related to their industry. In attempting to explain differences in both the level and growth of labor productivity at the firm level, it is important to control for industry.

\footnotetext{
${ }^{9}$ The exception seems to be home furniture, furnishings, and equipment stores that show an overall decline for continuing firms of $-1.4 \%$ for all 1992 firms, but the average change in weighted productivity in our matched subset shows an increase of $5.7 \%$.

${ }^{10}$ Except for Building Materials, Hardware, Garden Suppy, and Mobile Home Dealer (SIC 52) and Miscellaneous Retail (SIC 59) that invest .015 and .018, respectively.
} 


\section{Results on IT and retail productivity}

The matched AES-CRT dataset allows us to exploit cross sectional variation in the intensity of computer and total capital investment to see if firms that invested heavily in IT equipment or capital in 1992 enjoyed higher productivity in 1992 and whether they experienced higher productivity growth over the 1992 to 1997 period. Productivity is only one measure of firm performance, however. In the retail sector, perhaps more so than other sectors, increases in the number of establishments a retail firm operates is a good signal of a firm's success. Many retail markets are primarily local, and therefore in order for a firm to expand, it has to open new establishments in different geographic areas. An appealing aspect of this metric of performance is that we have high quality data on firm establishment growth.

Our model takes the following form, where $j$ indexes firms $s$ indexes size classes and $I$ indexes industries:

$$
y_{j}=\beta_{s} S I Z E_{j}+\beta_{I} I N D_{j}+f\left(I T_{j}, I_{j}\right)+\eta_{j}
$$

Where SIZE is a vector of employment size classes, IND is a vector of two-digit SIC dummies, IT is investment on information technology, and I is total capital investment. ${ }^{11}$ The dependent variable, $y_{j}$, is measured as the log of sales per worker in 1992,the log difference in sales per worker between 1992 and 1997, or as the growth in the number of establishments owned by the firm between 1992 and 1997.

Given the need to match heterogeneous units from the Census of Retail Trade and the Asset and Expenditure Survey, we are concerned about measurement error in our investment variables. We have explored various parameterizations of both the total investment and the IT component. The results were robust across all these specifications. We use a simple dummy variable to measure overall investment intensity. We group firms into high and low total investment categories as in Table 5. Namely, firms above the $75^{\text {th }}$ percentile in the distribution of firms with positive total investment spending per dollar of payroll are classified has having high investment (or capital) intensities. We specify the IT component of investment as its share of total investment $\left(\mathrm{IT}_{\mathrm{j}} / \mathrm{I}_{\mathrm{j}}\right)$ as in Dunne et. al. (2001).

\footnotetext{
${ }^{11}$ The construction of these measures means our analysis focuses on those firms that were active in both years. This could be a problem in light of the findings of FHK that show that net entry accounts for a large portion of aggregate productivity growth in the retail sector. However, recall their results are based on the net entry of establishments. We are looking at firms and, as table 2 shows, continuing firms (especially large ones) account for a substantial portion of net establishment entry.
} 
The productivity level and the productivity growth regressions are conditioned on firm characteristics measured in 1992. That is, we use cross sectional variation in 1992 firm characteristics to explain variation in firm performance measured by both level labor productivity in 1992 and growth in labor productivity between 1992 and 1997.

\section{A. Labor productivity regressions}

Table 8 presents the results for the 1992 productivity level regressions. Since our descriptive analysis above indicated large differences in firm performance across the retail firm size distribution, we also estimate the regressions using all firms in the sample and for small and large firms separately.

Model 1 in Table 8 shows the results for all firms in the sample. The coefficients on the firm size dummies show that smaller retailers are less productive relative to the largest firms. For instance, firms with less than ten employees are almost $40 \%$ less productive than firms with over 500 employees. We also find that retail firms that are more capital intensiveand have a higher IT share of investment have higher levels of labor productivity in 1992 even after controlling for firm size and industry. Firms that we consider "high" capital intensity firms are roughly $9.8 \%$ more productive than firms that are not. Further, there is a significant productivity premium associated with the share of capital that is IT.

Models 2 and 3 break out our results by two sub-samples. Model 2 shows results only for firms with 100 or fewer employees. We find for this sub-sample that firms with more than 50 but less than 100 employees are significantly more productive (ranging from $18.3 \%$ to $33.7 \%$ ) than the three size classes of firms that have less than 50 employees, very similar to the results in Model 1. However, the impact of both IT share and capital intensity for small firms is negligible. Model 3 shows that the largest two size classes are not significantly different from each other in term of productivity, but a $10 \%$ increase in the share of IT spending results in a $1.93 \%$ increase in labor productivity and firms that have high capital intensities are $12.9 \%$ more productive than those that are not.

In the following section we look at the effect of IT spending and capital intensity on the change in labor productivity between 1992 and 1997. 


\section{B. Labor productivity growth regressions}

The results from the labor productivity growth regressions are summarized in table 9. As in Table 8, we report estimates for all retailers in our sample and separately for small and large retail firms. The results for all firms are listed under Model 1. Unlike productivity levels, there is no discernable relationship between retail firm size and productivity growth between 1992 and 1997. In addition, the results indicate that more capital intensive firms (as measured by a firm's position in the 1992 investment distribution) experienced lower productivity growth over the 1992 to 1997 period, although they started at a higher position, as shown in Table 8. However, we do see that firms that invest a higher share in IT equipment also enjoy higher productivity growth controlling for all the other factors in the model, although this result is not statistically significant.

Models 2 and 3 in Table 9 list the results for the productivity growth regressions estimated separately for small and large firms. The coefficients on the IT share variable are positive and significant for the large firm sample and negative and insignificant for the small firm sample. While the difference in the estimates is not statistically significant, this result is suggestive that large firms were more able to exploit IT investments to improve productivity in the 1990's.

One well-known issue that arises in estimating (2) is that there may be an unobserved component that is related to the choice of inputs, and hence the coefficients will be biased. For instance, Olley and Pakes (1996) address this problem by posing that this unobserved component (such as managerial quality) will also be related to investment, the intuition being that good firms will likely invest more than other firms. Therefore, the coefficients on the investment and IT variables may be biased upwards. We estimated all of the models in table 9 using the growth rate in the number of establishments as a control; much like investment was used as a control in Olley and Pakes. However, the coefficients on this variable were rarely very large or statistically significant. Also, the coefficients on the capital and IT variables did not change with the inclusion of the growth in number of establishments variable.

\section{Establishment growth regressions}

Since the growth in the establishments is an interesting measure of retail firm performance and since we believe it is a high quality measure, we estimated (2) with establishment growth as the dependent variable. In results not presented, we found no clear relationship between capital intensity or the share of investment dedicated to IT and the growth in the number of retail establishments operated by retail firms. This suggests that, in retail, IT use is most likely 
associated with improved logistics and other cost side factors. Perhaps strategies that affect the demand side, such as advertising, product mix and so on, explain why some firms increase market share and expand into new markets by opening new retail establishments.

Overall, there appears to be a strong relationship between IT investment and productivity growth for retail firms, and this result is robust to several alternative measures of IT investment. Many prognosticators in the 1990's predicted that Internet based e-commerce would allow small retailers to use IT to compete more effectively with large ones. With our sample, we are able to measure the characteristics of retailers right at the cusp of the boom. The results in Tables 8 and 9 suggest it was the large retailers that found ways to effectively use IT to boost performance. In addition, the results from Table 2 show that the increases in retail activity over the1992 to 1997 period were largely concentrated at large retail firms.

Unfortunately, micro data from the 2002 Census of Retail Trade are not yet available to update the analysis past 1997 . In addition, it will continue to be a challenge to perform mic ro data analyses of the relationship between IT and performance for retailers since data on performance and investment continue to be collected in different surveys using different statistical units.

\section{Conclusions}

The retail trade sector in the U.S. has experienced considerable growth over the last several years. In addition, the sector has enjoyed substantial productivity growth over the same period. The reasons for this impressive performance are not well understood and there is, generally, little focus on the sector by researchers. Part of this lack of attention can be attributed to a lack of good micro level data with which to study the retail sector. In this paper, we have brought different Census Bureau micro datasets together for the first time to examine potential explanations of productivity growth among firms in the retail sector.

In particular we focus on the role played by computer investment. There is a sense in the popular imagination that large, technically sophisticated retailers are displacing smaller retailers. It is also widely thought that an important part of the business plan of these larger sophisticated retailers is a heavy reliance on information technology. Thus, we examine the relationship between IT intensity and labor productivity and retail establishment growth.

We provide a variety of statistics to try to describe changes in the retail sector, at the micro level over the 1992 to 1997 period, and attempt to discern what role, if any, investment in IT had in them. We show that increases in retail establishments and employment are dominated by large 
continuing firms. Large firms also account for most of the investment in the retail sector. Using some simple regressions, we find that there is a significant relationship between IT investment and retail productivity and productivity growth at the firm level. We do not find a significant relationship between IT spending and establishment growth at retail firms.

The patterns we see in the data are consistent with anecdotal evidence that many areas in retail are seeing large sophisticated companies introducing new technologies and processes and displacing less sophisticated retailers. However, there is more that needs to be done before we can more fully describe this process. We would like incorporate data from the Annual Retail Trade Survey so that we can analyze the relationship between computer investment and both value added per employee (rather than sales per employee) and inventories. Considerable data work needs to be done before we can do this, however. There is also more to do on examining how measures of technical sophistication like computer investment interact with entry and exit patterns of both firms and establishments to yield improved performance in the retail sector. Finally, we want to expand our analysis to cover other trade and services sectors that have witnessed large investments in IT. 


\section{References}

Abernathy, F., J. Dunlop, J. Hammond, and Weil (1999), A Stitch in Time: Lean Retailing and the Transformation of Manufacturing in Abernathy, F., J Dunlop, and J. Hammond eds. Lessons from the Apparel and Textile Industries, Oxford University Press, New York.

Atrostic, B.K., J. Gates and R. Jarmin (2001), Measuring the Electronic Economy at the U.S. Census Bureau, forthcoming in Proceedings of Statistics Canada Symposium 2001: Achieving Data Quality in a Statistical Agency: A Methodological Perspective.

Baldwin, J., R. Jarmin and J. Tang, (2001), The trend to smaller producers in manufacturing: A U.S./Canada Comparison, Working Paper CES-WP-02-06, Center for Economic Studies, U.S. Census Bureau, Washington, DC.

Bartelsman, Eric and Mark Doms, (2000), Understanding Productivity: Lessons from Longitudinal Micro data, Journal of Economic Literature, September.

Bosworth, B and J. Triplett (2000), Numbers Matter, Brookings Policy Brief No. 63, July 2000.

Bresnahan, T., E. Brynjolfson, and L. Hitt (1999), Information Technology, Workplace Organization, and the Demand for Skilled Labor: Firm Level Evidence, Sloan School of Management Working Paper, MIT, Cambridge, MA.

Dumas, Mark, Productivity Trends in Two Retail Trade Industries, 1987-1995, Monthly Labor Review, July 1997, pp. 35-39.

Dunne, T., L. Foster, J. Haltiwanger and K. Troske, (2001), Wage and productivity dispersion in U.S. manufacturing; the role of computer investment, mimeo Center for Economic Studies, U.S. Census Bureau, Washington, DC.

Foster, Lucia, John Haltiwanger and C.J. Krizan (2002), The Link Between Aggregate and Micro Productivity Growth: Evidence from Retail Trade, NBER Working Paper No. 9120.

Haltiwanger, J. and R. Jarmin (2000), Measuring the digital economy, in Brynolfsson, E. and B. Kahin eds. Understanding the Digital Economy: Data, Tools, Research, MIT Press, Cambridge.

McKinsey (2001), U.S. Productivity Growth 1995-2000: Understanding the contribution of Information Technology relative to other factors, McKinsey Global Institute.

McKinsey (2002), How IT Enables Productivity Growth, McKinsey Global Institute

Oliner, S., and D. Sichel (2000), The resurgence of growth in the late 1990s: Is information technology the story?, Journal of Economic Perspectives, 14(4), pp. 3-22.

Olley, S. and A. Pakes (1996), The Dynamics of Productivity in the Telecommunications Equipment Industry, Econometrica, 64(6), pp. 1263-98 
Schreyer, P., (2000), The contribution of information and communication technology to output growth: a study of the G7 countries, STI working paper 2000/2, OECD, Paris.

Stiroh, K. (2003), Reassessing the Role of IT in the Production Function: A Meta-Analysis, working paper, New York Federal Reserve.

U.S. Census Bureau, (1996), 1992 Census of Retail Trade. Subject Series: Measures of value produced, capital expenditures, depreciable assets and operating expenses, RC92-S-2, G.P.O., Washington, DC. 
Table 1: Basic Facts for Retail and Wholesale Trade

\begin{tabular}{|c|c|c|c|c|c|c|c|c|}
\hline & 1991 & 1992 & 1993 & 1994 & 1995 & 1996 & 1997 & 1998 \\
\hline \multicolumn{9}{|c|}{${\text { Output by Industry (Billions, } \$ 1992)^{1}}^{1}$} \\
\hline Total (GDP) & $6,318.9$ & $6,642.3$ & $7,054.3$ & $7,400.5$ & $7,813.2$ & $8,318.4$ & $8,790.2$ & $9,299.2$ \\
\hline Trade & 966.3 & $1,010.5$ & $1,099.8$ & $1,147.4$ & $1,216.7$ & $1,307.3$ & $1,407.7$ & $1,499.7$ \\
\hline Retail & 551.7 & 578.0 & 620.6 & 646.8 & 687.1 & 740.5 & 796.8 & 856.4 \\
\hline Wholesale & 414.6 & 432.5 & 479.2 & 500.6 & 529.6 & 566.8 & 610.9 & 643.3 \\
\hline Manufacturing & $1,082.00$ & $1,131.4$ & $1,223.2$ & $1,289.1$ & $1,316.0$ & $1,379.6$ & $1,436.0$ & $1,500.8$ \\
\hline \multicolumn{9}{|c|}{ Total Nonfarm Employees ${ }^{2}$} \\
\hline & 108,591 & 110,692 & 114,135 & 117,188 & 119,597 & 122,677 & 125,845 & 128,772 \\
\hline Trade & 25,352 & 25,753 & 26,664 & 27,564 & 28,078 & 28,614 & 29,095 & 29,712 \\
\hline Retail & 19,355 & 19,772 & 20,501 & 21,187 & 21,596 & 21,966 & 22,295 & 22,788 \\
\hline Wholesale & 5,997 & 5,982 & 6,163 & 6,377 & 6,482 & 6,648 & 6,800 & 6,924 \\
\hline Manufacturing & 18,106 & 18,076 & 18,323 & 18,526 & 18,496 & 18,675 & 18,806 & 18,543 \\
\hline
\end{tabular}

\section{Crude Labor Productivity (1000s \$1992/employee)}

$\begin{array}{lllllllll}\text { Total } & 58.2 & 60.0 & 61.8 & 63.2 & 65.3 & 67.8 & 69.8 & 72.2 \\ \text { Trade } & 38.1 & 39.2 & 41.2 & 41.6 & 43.3 & 45.7 & 48.4 & 50.5 \\ \text { Retail } & 28.5 & 29.2 & 30.3 & 30.5 & 31.8 & 33.7 & 35.7 & 37.6 \\ \text { Wholesale } & 69.1 & 72.3 & 77.8 & 78.5 & 81.7 & 85.3 & 89.8 & 92.9 \\ \text { Manufacturing } & 59.8 & 62.6 & 66.8 & 69.6 & 71.1 & 73.9 & 76.4 & 80.9\end{array}$

Crude Labor Productivity Growth (percent change from prior period)

\begin{tabular}{llllllll} 
Total & 3.1 & 3.0 & 2.2 & 3.4 & 3.8 & 3.0 & 3.4 \\
Trade & 2.9 & 5.1 & 0.9 & 4.1 & 5.4 & 5.9 & 4.3 \\
Retail & 2.6 & 3.6 & 0.8 & 4.2 & 6.0 & 6.0 & 5.2 \\
Wholesale & 4.6 & 7.5 & 0.9 & 4.1 & 4.4 & 5.4 & 3.4 \\
Manufacturing & 4.7 & 6.7 & 4.2 & 2.2 & 3.8 & 3.4 & 6.0 \\
\hline
\end{tabular}

${ }^{1}$ Source: BEA, Gross Product by Industry Employ. (1000s)

${ }^{2}$ Source: BLS 
Table 2: Descriptive Statistics for All Retail Firms by Firm Size: 1992 and 1997

\begin{tabular}{|c|c|c|c|c|c|c|c|}
\hline Employment Size Class & $0-9$ & $10-19$ & $20-49$ & $50-99$ & $100-499$ & $500+$ & Total \\
\hline Number of firms, 1992 & 814,902 & 137,236 & 84,545 & 22,402 & 10,794 & 1,858 & $1,071,737$ \\
\hline Number of continuing firms & 370,866 & 79,615 & 53,073 & 15,181 & 7,941 & 1,463 & 528,139 \\
\hline Number of firms, 1997 & 806,329 & 144,137 & 92,374 & 25,507 & 12,437 & 2,071 & $1,082,855$ \\
\hline Number of establishments, 1992 & 814,902 & 157,301 & 119,455 & 50,661 & 81,634 & 292250 & $1,526,215$ \\
\hline Change due to net entry & 2,020 & 1,491 & 5,115 & 2,999 & $-1,660$ & -4027 & 5,938 \\
\hline Change due to within class continuers & $-1,367$ & -955 & $-1,046$ & -48 & 2,755 & 26,496 & 25,835 \\
\hline Change due to cross class continuers & $-5,335$ & $-4,314$ & $-3,688$ & -385 & 2,925 & 14,004 & 3,207 \\
\hline Number of establishments, 1997 & 813,492 & 159,847 & 125,096 & 54,254 & 82,480 & 326,026 & $1,561,195$ \\
\hline Employment,1992 & $2,558,086$ & $1,829,730$ & $2,528,883$ & $1,502,267$ & $1,991,904$ & $7,997,583$ & $18,408,453$ \\
\hline Net change from net entry of firms & $-43,114$ & 29,578 & 96,627 & 96,579 & 188,726 & $-173,340$ & 125,236 \\
\hline Net change due to within class continuers & 91,528 & 12,710 & 38,330 & 23,244 & 96,250 & $1,949,521$ & $2,211,583$ \\
\hline Net change due to cross class continuers & $-37,184$ & 54,669 & 99,820 & 90,940 & 74,764 & 138,581 & 421,590 \\
\hline Employment,1997 & $2,596,316$ & $1,925,867$ & $2,763,660$ & $1,713,030$ & $2,281,644$ & $9,912,345$ & $21,165,862$ \\
\hline
\end{tabular}

Source: Author's calculations using the 1992 and 1997 Census of Retail Trade micro-data files, Center for Economic Studies. Note that "firm" refers to the operations of and enterprise within a two-digit retail SIC. A firm with establishments in more than one two-digit retail SIC will enter the data multiple times.

Table 3: Descriptive Statistics for All Retail Firms: 1992 and 1997

\begin{tabular}{lcccccccc} 
Employment Size Class & $0-9$ & $10-19$ & $20-49$ & $50-99$ & $100-499$ & $500+$ & Entrants & Exiters \\
\hline Number of firms, 1992 & 814,902 & 137,236 & 84,545 & 22,402 & 10,794 & 1,858 & NA & 543,598 \\
Number of firms 1997 & 806,329 & 144,137 & 92,374 & 25,507 & 12,437 & 2,071 & 554,716 & NA \\
Average LP, 1992 & 4.267 & 3.940 & 3.905 & 4.084 & 4.126 & 4.309 & NA & 4.016 \\
Average LP, 1997 & 4.345 & 4.043 & 3.982 & 4.233 & 4.319 & 4.358 & 4.182 & NA \\
Average LP Growth & -0.057 & 0.092 & 0.110 & 0.133 & 0.152 & 0.100 & NA & NA
\end{tabular}

Source: Author's calculations using the 1992 and 1997 Census of Retail Trade micro-data files, Center for

Economic Studies. Note that "firm" refers to the operations of and enterprise within a two-digit retail SIC. A firm with establishments in more than one two-digit retail SIC will enter the data multiple times. Labor productivity

(LP) is the natural log of sales per employee. 


\section{Table 4: Descriptive Statistics for Firms in Matched Subset: 1992 and 1997}

\section{(Total unweighted - means weighted)}

Employment Size Clas

\section{Number of firms, 1992}

$0-9$

Number of continuing firms, 1997

7,980

4,491

8,963

4,969

33,172

19,594

Number of establishments at continuers, 1997

Employment in 1992

$2,449,588$

Weighted employment, 1992

$1,687,191$

5,269

Average weighted total investment, 1992

Average weighted computer investment, 1992

Average weighted computer share of total investment, 1992

327

0.080

$-0.051$

10-19

$\begin{array}{lll}10-19 & 20-49 & 50-99 \\ 2,926 & 2,630 & 1,256\end{array}$

$1,846 \quad 1,795$

$4,288 \quad 5,683$

$2,554 \quad 3,711$

$39,587 \quad 82,262$

$25,359 \quad 56,294$

Average weighted LP growth

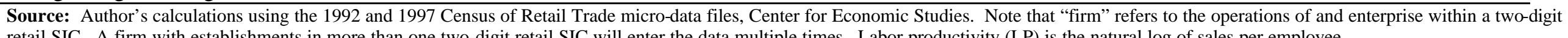


Table 5: Descriptive Statistics for Firm Investment Matched Subset - 1992 and 1997

\begin{tabular}{|c|c|c|c|c|c|c|c|}
\hline Investment Intensity Category & No Investment & LT-No IT & LT-LIT & LT-HIT & HT-No IT & HT-LIT & HT-HIT \\
\hline Number of firm observations & 6,036 & 3,185 & 4,434 & 1,058 & 660 & 757 & 702 \\
\hline Number of establishments, 1992 & 10,345 & 24,516 & 93,939 & 17,883 & 6,770 & 48,972 & 35,405 \\
\hline Number of establishments at continuers, 1997 & 6,661 & 22,359 & 83,538 & 16,102 & 7,404 & 45,778 & 35,118 \\
\hline Employment, 1992 & 115,162 & 469,388 & $2,128,848$ & 290,275 & 173,623 & $1,276,819$ & $1,904,412$ \\
\hline Employment at continuers, 1997 & 85,626 & 439,216 & $2,093,623$ & 285,278 & 200,076 & $1,475,648$ & $2,486,125$ \\
\hline Weighted employment, 1992 & $3,164,505$ & $2,871,504$ & $4,664,406$ & 783,048 & 724,765 & $2,032,257$ & $2,197,014$ \\
\hline Weighted continuer employment, 1997 & $2,225,994$ & $2,514,524$ & $3,902,154$ & 626,411 & 740,286 & $2,062,428$ & $2,809,275$ \\
\hline Average weighted computer investment per dollar payroll & 0.0 & 0.0 & 0.006 & 0.038 & 0.0 & 0.008 & .0127 \\
\hline Average weighted computer share of total investment & -- & 0.0 & 0.085 & 0.354 & 0.0 & 030 & .0174 \\
\hline Average weighted LP, 1992 & 4.235 & 40315 & 4.073 & 4.001 & 4.407 & 4.804 & 4.225 \\
\hline Average weighted LP, 1997 & 4.295 & 4.416 & 4.373 & 40425 & 4.413 & 40152 & 4.552 \\
\hline Average weighted LP growth & -0.012 & -0.016 & 0.042 & 0.027 & -0.052 & 0.025 & 0.164 \\
\hline
\end{tabular}

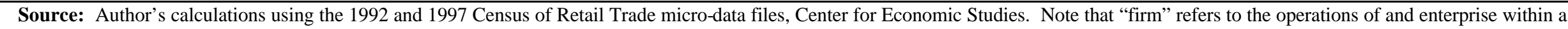

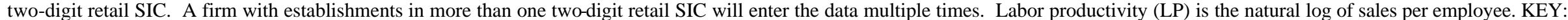

LT=Low Total Investment, HT=High Total Investment, LIT=Low IT Investment, HIT=High IT Investment

\section{Table 6: Descriptive Statistics by Two-Digit SIC: All 1992 Firms}

\begin{tabular}{|c|c|c|c|c|c|c|c|c|}
\hline Two-Digit SIC & 52 & 53 & 54 & 55 & 56 & 57 & 58 & 59 \\
\hline Number of firms, 1992 & 55,199 & 10,264 & 127,575 & 142,256 & 63,020 & 79,610 & 331,488 & 262,325 \\
\hline Average employment, 1992 & 12 & 203 & 23 & 14 & 18 & 9 & 20 & 9 \\
\hline Average survivor employment, 1997 & 12 & 235 & 21 & 12 & 15 & 8 & 15 & 8 \\
\hline Average number of establishments, 1992 & 1.3 & 3.4 & 1.4 & 1.4 & 2.3 & 1.4 & 1.3 & 1.3 \\
\hline Average number of establishments at survivors, 1997 & 0.8 & 2.8 & 0.8 & 1.0 & 1.4 & 0.8 & 0.8 & 0.8 \\
\hline Average LP, 1992 & 4.60 & 4.28 & 4.43 & 5.09 & 4.16 & 4.52 & 3.40 & 4.30 \\
\hline Average survivor LP, 1997 & 4.74 & 4.38 & 4.56 & 5.29 & 4.32 & 4.64 & 3.49 & 4.47 \\
\hline Average change in LP at survivors & $1.8 \%$ & $-7.3 \%$ & $-3.4 \%$ & $3.8 \%$ & $-5.4 \%$ & $-1.4 \%$ & $-2.4 \%$ & $1.7 \%$ \\
\hline
\end{tabular}

Source: Authors calculations 1992 and 1997 Census of Retail Trade and 1992 Assets and Expenditures Survey micro data files, Center for

Economic Studies. Note "firm" refers to the operations of an enterprise within given two-digit retail SIC. A firm with establishments in more

than one two-digit retail SIC will enter the data multiple times. Labor productivity (LP) is the natural log of sales per employee. 
Table 7: Descriptive Statistics by Two-Digit Industry: Matched Subset

\begin{tabular}{|c|c|c|c|c|c|c|c|c|}
\hline Two-Digit SIC & 52 & 53 & 54 & 55 & 56 & 57 & 58 & 59 \\
\hline Number of firms, 1992 & 783 & 640 & 1278 & 3390 & 2436 & 2851 & 1497 & 3957 \\
\hline Average weighted employment, 1992 & 11.7 & 215.0 & 22.6 & 13.9 & 15.4 & 8.8 & 22.2 & 8.8 \\
\hline Average weighted employment at continuers, 1997 & 20.2 & 488.6 & 36.5 & 20.9 & 25.5 & 12.5 & 34.0 & 12.9 \\
\hline Average weighted number of establishments, 1992 & 1.3 & 3.1 & 1.4 & 1.4 & 2.3 & 1.3 & 1.4 & 1.3 \\
\hline Average weighted number of establishments, 1997 & 0.8 & 2.6 & 0.9 & 1.0 & 1.5 & 0.8 & 0.9 & 0.8 \\
\hline Average weighted LP, 1992 & 4.54 & 4.36 & 4.32 & 5.05 & 4.19 & 4.57 & 3.39 & 4.29 \\
\hline Average weighted LP, 1997 & 4.77 & 4.52 & 4.40 & 5.26 & 4.33 & 4.69 & 3.52 & 4.42 \\
\hline Average weighted change in LP & $3.7 \%$ & $-6.7 \%$ & $-3.1 \%$ & $3.2 \%$ & $-3.0 \%$ & $5.7 \%$ & $-1.3 \%$ & $0.2 \%$ \\
\hline Average weighted capital expenditures, 1992 & 29,688 & $4,078,551$ & 47,463 & 27,297 & 24,346 & 16,999 & 31,282 & 17,571 \\
\hline Average weighted computer expenditures, 1992 & 2,879 & 87,568 & 1,725 & 1,864 & 2,058 & 1,705 & 988 & 1,812 \\
\hline Average weighted capital expenditures per dollar of payroll, 1992 & 0.162 & 0.137 & 0.148 & 0.152 & 0.175 & 0.159 & 0.130 & 0.214 \\
\hline Average weighted computer expenditures per dollar of payroll, 1992 & 0.015 & 0.009 & 0.004 & 0.006 & 0.008 & 0.007 & 0.003 & 0.018 \\
\hline
\end{tabular}

Average weighted computer expenditures per dollar of payroll, 1992

Source: Authors calculations 1992 and 1997 Census of Retail Trade and 1992 Assets and Expenditures Survey Micro Data files, Center for Economic Studies. Note "firm" refers to the operations of an enterprise within given 2-digit retail SIC. A firm with establishments in more than one 2-digit retail SIC will enter the data multiple times. Labor productivity (LP) is the natural log of sales per employee. 


\section{Table 8: Labor Productivity Regressions}

Dependent Variable: $\mathrm{LP}_{92}=\log \left(\right.$ sales $_{92} /$ employment $\left._{92}\right)$, regressions are weighted by adjusted sample weights

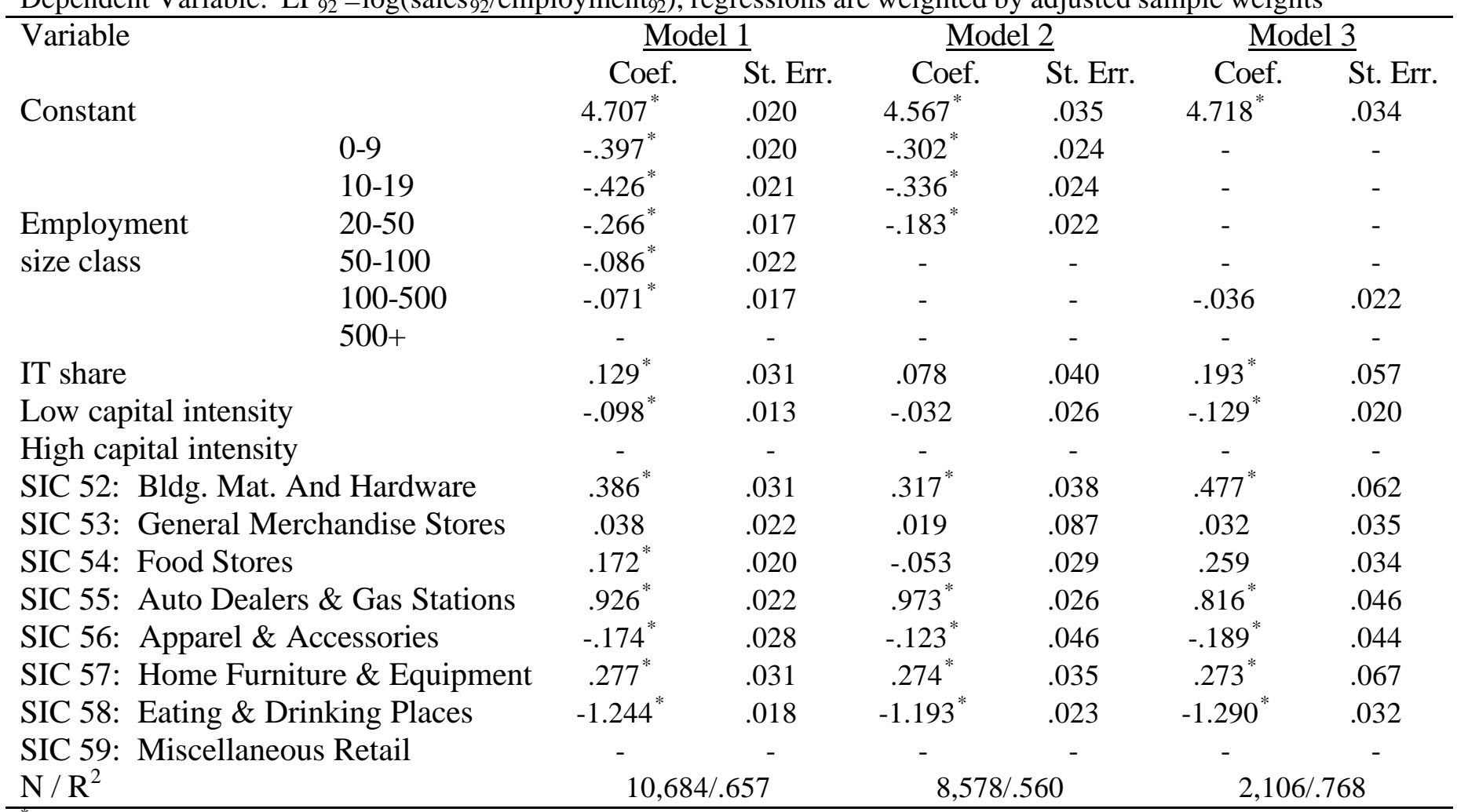

"means the coefficient is significant at the $5 \%$ level 


\section{Table 9: Growth of Labor Productivity Regressions}

Dependent Variable: $\log \left(\mathrm{LP}_{92} / \mathrm{LP}_{97}\right)$, regressions are weighted by adjusted sample weights

\begin{tabular}{|c|c|c|c|c|c|c|c|}
\hline \multicolumn{2}{|c|}{ Variable } & \multicolumn{2}{|c|}{ Model 1} & \multicolumn{2}{|c|}{ Model 2} & \multicolumn{2}{|c|}{ Model 3} \\
\hline \multirow{3}{*}{ Constant } & & Coef. & St. Err. & Coef. & St. Err. & Coef. & St. Err. \\
\hline & & $.069^{*}$ & .017 & $.158^{*}$ & .030 & .019 & .027 \\
\hline & $0-9$ & $-.087^{*}$ & .019 & $-.080^{*}$ & .022 & - & - \\
\hline \multirow{5}{*}{$\begin{array}{l}\text { Employment } \\
\text { size class }\end{array}$} & $10-19$ & -.010 & .019 & .003 & .021 & - & - \\
\hline & $20-50$ & $.042^{*}$ & .015 & $.061^{*}$ & .019 & - & - \\
\hline & $50-100$ & -.021 & .018 & - & - & - & - \\
\hline & $100-500$ & -.005 & .014 & - & - & -.008 & .018 \\
\hline & $500+$ & - & - & - & - & - & - \\
\hline \multicolumn{2}{|l|}{ IT share } & .043 & .026 & -.021 & .034 & $.102^{*}$ & .044 \\
\hline \multicolumn{2}{|c|}{ Low capital intensity } & $.056^{*}$ & .010 & -.017 & .022 & $.075^{*}$ & .015 \\
\hline \multicolumn{2}{|c|}{ High capital intensity } & - & - & - & - & - & - \\
\hline \multicolumn{2}{|c|}{ SIC 52: Bldg. Mat. And Hardware } & $-.057^{*}$ & .027 & -.044 & .033 & -.077 & .049 \\
\hline \multicolumn{2}{|c|}{ SIC 53: General Merchandise Stores } & -.000 & .018 & -.101 & .081 & .038 & .028 \\
\hline \multicolumn{2}{|c|}{ SIC 54: Food Stores } & $-.052^{*}$ & .017 & $-.105^{*}$ & .026 & -.016 & .027 \\
\hline \multicolumn{2}{|c|}{ SIC 55: Auto Dealers \& Gas Stations } & $.052^{*}$ & .019 & .008 & .023 & $.102^{*}$ & .036 \\
\hline \multicolumn{2}{|c|}{ SIC 56: Apparel \& Accessories } & $.076^{*}$ & .023 & $-.100^{*}$ & .046 & $.131^{*}$ & .035 \\
\hline \multicolumn{2}{|c|}{ SIC 57: Home Furniture \& Equipment } & .029 & .027 & .028 & .031 & .021 & .053 \\
\hline \multicolumn{2}{|c|}{ SIC 58: Eating \& Drinking Places } & $-.052^{*}$ & .015 & $-.094^{*}$ & .021 & -.018 & .026 \\
\hline \multicolumn{2}{|c|}{ SIC 59: Miscellaneous Retail } & \multirow{2}{*}{\multicolumn{2}{|c|}{$7,174 / .021$}} & \multirow{2}{*}{\multicolumn{2}{|c|}{$\begin{array}{r}- \\
5,327 / .016\end{array}$}} & \multirow{2}{*}{\multicolumn{2}{|c|}{$\overline{1,847 / .042}$}} \\
\hline \multicolumn{2}{|c|}{$\mathrm{N} / \mathrm{R}^{2}$} & & & & & & \\
\hline
\end{tabular}

means the coefficient is significant at the $5 \%$ level 